\title{
NARZECZONA W TAFLI LODU, CZYLI JAK KINO MAWIA O NIEPRZENIKNIONOŚCI UCZUĆ MIŁOSNYCH (45 LAT ANDREW HAIGHA)
}

BRYGIDA PAWŁOWSKA-JĄDRZYK

Wydział Nauk Humanistycznych UKSW

Faculty of Humanities, Cardinal Stefan Wyszyński University in Warsaw

brygida.pawlowska@gmail.com

\section{I.}

Film 45 lat (45 Years, reż. Andrew Haigh, Wielka Brytania 2015), będący adaptacją opowiadania In Another Country Davida Constantine'a, osnuty jest na prawdziwie zaskakującym pomyśle. Starszy mężczyzna, Geoffrey Marcer (Tom Courtenay), tuż przed obchodami czterdziestej piątej rocznicy swojego ślubu z Kate (Charlotte Rampling) otrzymuje list, który wstrząsa ustabilizowanym życiem małżonków, zmuszając ich do zadumy nad przeszłością i rewizji wartości, na jakich opiera się ich związek. Niespodziewana wiadomość spada na tę parę jak grom z jasnego nieba: otóż w Alpach Szwajcarskich właśnie odnaleziono ciało pierwszej ukochanej Geoffa - dziewczyny o imieniu Katya, która z górą pół wieku temu, podczas wspólnych wakacji z narzeczonym, zginęła tragicznie, osunąwszy się w szczelinę lodowca. Niezwyczajne okoliczności jej śmierci po latach nabiorą szczególnego znaczenia, znajdując także odzwierciedlenie w planie symbolicznym filmu.

Geoff przeżywa wstrząs egzystencjalny i dość nieudolnie komunikuje o swoich emocjach żonie. Chociaż właściwie nie ma pewności, czy tkwiące w lodowcu ciało jest t y m wła śn ie ciałem (to wciąż jedynie niesprawdzona hipoteza), widmo zmarłej ukochanej oraz echa dawnych uczuć zaczynają anektować różnorodne sfery życia małżonków, wnosząc do ich dotychczas harmonijnego związku lęki i obawy, pierwiastek obcości i klimat niezrozumienia. Szokująca nowina w sposób tyleż nagły, ile bezwzględny konfrontuje Geoffa nie tylko ze wspomnieniami młodości, ale i z dojmującą 
konkretnością starzenia się i przemijania. Mężczyzna tak oto tłumaczy żonie swą bolesną konsternację:

Leżała tam ponad pięćdziesiąt lat, jak w lodówce. A teraz ją znaleźli, jak „człowieka z Tollund”. [...] Kiedy roztopił się śnieg, został tylko sam lód, i wtedy ją odkryli. Ciągle tam jest. Pod lodem. Woda musi być tam przezroczysta, dlatego ją dostrzegli. [...] Lotnicy na Islandii byli w doskonałym stanie, widziałem dokument. Wyglądali jak żywi, bo szybko zamarzli. Jakie to wszystko dziwne... Będzie wyglądać jak w sześćdziesiątym drugim roku. A ja wyglądam tak...

\section{II.}

Motyw przezroczystej lodowej „krypty” jest zatem w fabule obrazu brytyjskiego reżysera realistycznie umotywowany, ale, co warto podkreślić, do końca istnieje jedynie w sferze wyobrażeń - zarówno odbiorców, jak i postaci przedstawionych (wbrew pierwotnym planom, Geoff ulegnie naciskom żony i ostatecznie nie pojedzie do Szwajcarii, by zobaczyć odnalezione ciało). W konsekwencji, paradoksalnie, widmo ukochanej z przeszłości nabiera, w życiu bohaterów filmu i jego widzów jeszcze większej „mocy rażenia” zdaje się imaginacyjnie intensyfikować i wpisywać w sfery doświadczeń wewnętrznych o charakterze fantazmatycznym, uruchamiając pokłady znaczeń antropologiczno-archetypowych.

Narracja 45 lat prowadzona jest konsekwentnie z punktu widzenia Kate, niespiesznie i spokojnie, choć pod jej powierzchnią wyczuwa się głębinowy niepokój, żal oraz inne - tyleż enigmatyczne, ile trudne - emocje. Sam reżyser wypowiada się o bohaterce kreowanej przez Charlotte Rampling z empatią i zrozumieniem:

${ }^{1}$ Człowiek z Tullund - pochodzące z epoki żelaza zmumifikowane zwłoki mieszkańca Półwyspu Jutlandzkiego, odnalezione w 1950 roku na torfowisku nieopodal Silkeborga w Danii; G. Sanik, Człowiek z Tollund - twarz sprzed ponad 2300 lat, 1.11.2015, Eloblog; https://eloblog.pl/czlowiek-z-tollund-twarz-sprzed-po nad-2300-lat/ [dostęp: 2.08.2019]. Inny tego rodzaju przykład przywołuje polski „eseista przezroczystości” - M. Bieńczyk, Przezroczystość, Kraków 2007, s. 13. 
Czuję wielką sympatię do Kate. Z pewnością jest jakaś irracjonalność w jej uczuciach, czego ona jest świadoma, ale jednocześnie jest w tych uczuciach coś głębszego i niepokojącego. To tak, jakby skupianie się na ich związku [tj. na relacji Geoffa z pierwszą narzeczoną - przyp. B.P.J.] powodowało mdłości, których Kate nie może się pozbyć. Chodzi o uczucie odrzucenia i zazdrości, ale także o odczuwanie sensu życia. To tak, jakby pod ciężarem chęci kontrolowania przez nią tej trudnej sytuacji wszystko, co zbudowała na przestrzeni lat, zaczęło tracić swoje znaczenie. Wszystko rozpada się na kawałki, a ona nie jest pewna, jak poskładać je znowu razem².

Reakcji bohaterki filmu na nową sytuację raczej nie da się sprowadzić do poczucia retrospektywnej zazdrości. Kate wydaje się nade wszystko „głębinowo zdezorientowana" i przytłoczona uświadomieniem sobie faktu, że życie, które dotąd wiodła, oraz relacja z mężem, wokół której je zorganizowała, prawdopodobnie były czymś innym, niż jej się przez te wszystkie lata zdawało. Jakież to potworne przypuszczenie, iż przez pół wieku być może mylnie się postrzegało istotę i sens własnego losu, istotę i sens więzów łączących nas z najbliższym człowiekiem! Takie rozpoznanie - poczynione już za progiem starości, ale i w nadziei na kolejne wspólne lata - musi wywołać gorycz i lęk wobec perspektywy rozliczeń z własnym życiem. Bo na takim etapie aktualnie znajduje się żona Geoffa - kobieta od dawna już niemłoda, bezdzietna i nieoczekiwanie przybita poczuciem osamotnienia.

Andrew Haigh w ten oto sposób tłumaczy, dlaczego zdecydował się na adaptację opowiadania Davida Constantine'a:

Było coś łamiącego mi serce w tej relacji, coś tak niepewnego jak przeszkoda na ostatnim okrążeniu. To tak, jakby to przypomnienie przeszłości, to zachowane w lodzie ciało, czekało na moment, aby pogrążyć wszystko w chaosie, w bardzo cichym, wewnętrznym chaosie. Przez szczeliny w ziemi wychodzą te wszystkie wątpliwości i obawy, wszystkie te rzeczy przemilczane przez lata, emocje tłumione i ukrywane. To tak, jakby cała ta relacja między Kate i Geoffem została nagle z góry zakwestionowana przez kobietę, która już nie istnieje $[\ldots]^{3}$.

2 Q \& A, Wywiad $z$ Andrew Haighem, materiały dołączone do wydania filmu 45 lat na płycie DVD, Solopan Sp. z o.o., 2015.

3 Ibidem. 


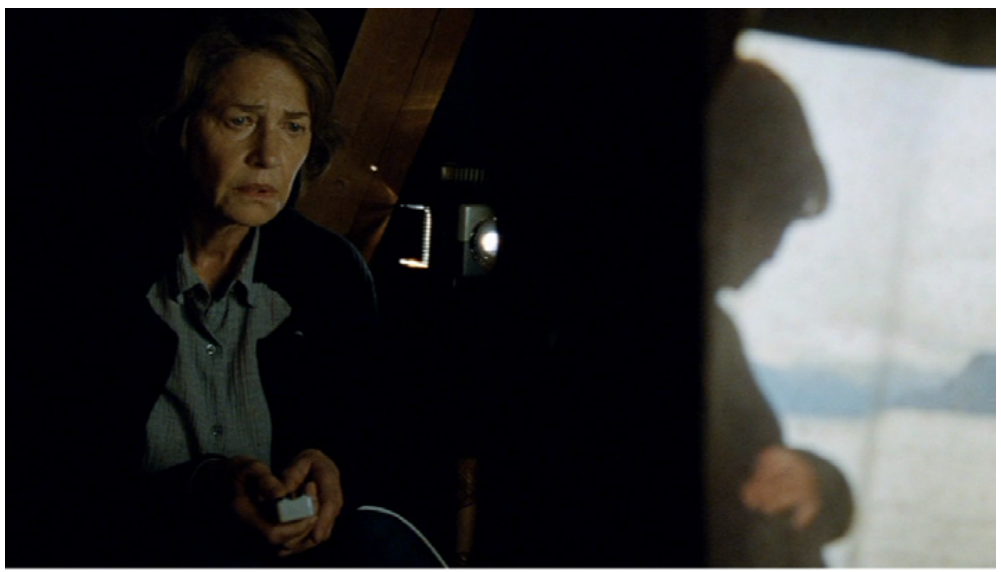

Il. 1. Kadr z filmu 45 lat (reż. Andrew Haigh). Kate przegląda na strychu ${ }^{4}$ slajdy, na których jej mąż przed pótwieczem utrwalił wizerunek swej pierwszej ukochanej. Tragicznie zmarła kobieta wydaje się uwięziona nie tylko $w$ tafli lodu, ale $i$ w przezroczach, które moga tu petnić funkcję fantazmatycznych ekranów wyobraźni (ich wyjątkowy status zostaje podkreślony na samym początku filmu, kiedy widzimy jedynie czarny obraz, ale styszymy dźwięk przesuwanych slajdów $)^{5}$

Można zatem sądzić, że reżyser świadomie sugeruje widzom nie tylko istnienie związku przyczynowo-skutkowego, ale i swoistego paralelizmu między „objawieniem się” kobiecego ciała, zakonserwowanego w lodzie niczym owad w bursztynie, a wyłonieniem się z mroku przemilczeń emocji i afektów ${ }^{6}$, które zdają się skłaniać męża Kate do rewizji własnej tożsamości. Czy jednak rzeczywiście mamy tu do czynienia z odsłonięciem istotowej treści życia wewnętrznego Geoffa, jaką byłoby przekraczające granice

4 Zob. w tym kontekście uwagi na temat podświadomych lęków, zrodzonych z imaginacji, jakie budzi w nas strych: G. Bachelard, Wyobraźnia poetycka. Wybór pism, wyb. H. Chudak, przedm. J. Błoński, tłum. H. Chudak, A. Tatarkiewicz, Warszawa 1975, s. 311 i nast.

5 Za tę uwagę dziękuję doktorowi Robertowi Birkholcowi.

${ }^{6} \mathrm{Na}$ temat wagi afektów w procesie pamięci zob. L. Nader, Afekt, [w:] Modi memorandi. Leksykon kultury pamięci, red. M. Saryusz-Wolska, R. Traba, Warszawa 2014, s. 31-32. Luiza Nader odróżnia podświadome afekty (proto-emocje) od świadomie doświadczanych emocji. 
śmierci, niezniszczalne uczucie do zmarłej kobiety, czy raczej z wywołaną danymi okolicznościami pracą pamięci, która prowadzi do nagłej „inwazji nostalgii” za czasem młodości? Na ile jego reakcja emocjonalna oraz tkliwe wspomnienia związane z pierwszą ukochaną naznaczone są teraźniejszością - chociażby żalem, lękiem czy sentymentami mężczyzny, który musi się już mierzyć z przemijaniem i wrażeniem zatracenia sensu życia? („Myślę, że najgorszym rodzajem zniedołężnienia jest utrata celowości” - wyznaje Geoff żonie, mimowolnie raniąc ją przy tym nostalgicznym stwierdzeniem, że zanim doszło do tragedii, on i Katya odważnie wędrowali przed siebie, odwracając się od cywilizacji.)

Trudno pominąć sformułowane powyżej wątpliwości, wszak, jak dowodzą badania nad pamięcią, wspomnienia nieprzerwanie się zmieniają i z zasady ulegają presji chwili obecnej, wypełniającym ją myślom i aktualnie przeżywanym uczuciom ${ }^{7}$. Jednak obraz brytyjskiego reżysera problemów tych z zasady nie uwypukla. Jak wspomniałam, filmowa opowieść prezentowana jest z punktu widzenia żony bohatera i szczególnie eksponuje typowo kobiece aspekty przeżywania intymnych relacji uczuciowych.

\section{III.}

Kate czuje się zawiedziona i zraniona zobojętnieniem męża, które manifestuje się wobec przygotowań do jubileuszu, tytułowej 45. rocznicy ich ślubu. Geoffrey, po otrzymaniu informacji o zaskakującym odkryciu, popada w „dziwny” nastrój i zaczyna stronić od ludzi: unika spotkań ze wspólnymi przyjaciółmi, nie chce się też angażować w decyzje dotyczące organizacji uroczystości, ukierunkowuje natomiast uwagę ku temu, co wiąże się z pierwszą narzeczoną - odgrzebuje stare zdjęcia, słucha dawnych szlagierów

7 „[...] Każde wspomnienie łączy dwa bieguny w czasie. To, co pamiętasz, mogło się wydarzyć wczoraj lub pół wieku temu, ale to, że pamiętasz to wydarzenie, rozgrywa się w czasie teraźniejszym. Przypominasz sobie coś teraz. Wskutek tego w tym wspomnieniu nie tylko pojawia się w chwili obecnej coś z twojego dawnego ja, lecz na odwrót, również do wspomnienia trafia coś z twoich uczuć i myśli z danej chwili. Wspomnienia nie są teczkami dokumentów, które po przejrzeniu wracają do pamięci w takim stanie, w jakim z niej przybyły. Zmieniają się w trakcie używania [...]"; D. Draaisma, Fabryka nostalgii. O fenomenie pamięci wieku dojrzałego, tłum. E. Jusewicz-Kalter, Wołowiec 2010, s. 151-152 [podkreśl. w oryginale]. 
i sięga po młodzieńcze lektury (Kierkegaard), szuka informacji o lodowcach, a nawet powraca do dawno porzuconego palenia papierosów. Kate boleśnie dotknięta, choć zawsze rzeczowa i opanowana, z pozoru wręcz chłodna - uświadamia sobie istnienie między nią a mężem sfery doznań emocjonalnych, która pozostaje dla niej niedostępna i nieprzenikniona. To z pewnością bardzo trudne, zwłaszcza wobec nieco naiwnej bezpośredniości Geoffa. Kobieta dowiaduje się, że nosi imię swej poprzedniczki, którą jej wybranek miał zamiar poślubić, że natura obdarzyła je obie podobnym kolorem włosów, wreszcie - że Katya w czasie tragicznego wypadku była brzemienna (fakt ów Geoff przemilcza, świadczą jednak o nim odnalezione na poddaszu slajdy). Reżyser, który z upodobaniem tropi niuanse psychologiczne związane z relacjami międzyosobowymi i metodycznie akcentuje różnorodne niedopowiedzenia ${ }^{8}$, również i tej bohaterki do końca „nie odsłania”. Nie dowiemy się na przykład, dlaczego Kate jest bezdzietna (można sądzić, że miejsce dziecka w życiu kobiety wypełnia pies, Maks) ${ }^{9}$, będziemy się też musieli sami uporać z interpretacją niejednoznacznego, „po mistrzowsku zainscenizowanego finału”, w którym kamera skupia się na wymowie jej twarzy - nie bez przyczyny jeden z krytyków nadał recenzji tego filmu tytuł Święto niepewności $i^{10}$.

8 W sferze niedopowiedzenia (pozostającej zapewne w związku z niepewnością Geoffreya) pozostaje na przykład charakter relacji, który łączył Katyę z przewodnikiem górskim, w obecności którego dziewczyna osunęła się w szczelinę lodowca. Sporo wskazuje na to, że Geoff był o niego zazdrosny.

9 Kate i Geoff nigdy wprost nie rozmawiają o dzieciach, być może dlatego, że jest to dla nich temat bolesny. Co znamienne, Kate powątpiewa w wartość wspomnień, manifestuje też niechęć do robienia i posiadania zdjęć. W rozmowie z mężem tłumaczy, że nie widzi w tym sensu, gdy się nie ma dzieci ani wnuków. Dopiero nowa sytuacja skłania ją do przewartościowania tych poglądów. Zapytana przez Geoffa, jakie zdjęcie ewentualnie powiesiłaby w domu, odpowiada, że np. Maksa, gdy był szczeniakiem.

${ }_{10}$ Tytuł ten wydaje się trafny, choć zakończenie filmu widzę jednak inaczej niż Piotr Czerkawski, który opisuje je następująco: „Podczas imprezy z okazji 45. rocznicy ślubu małżonkowie tańczą wspólnie do ulubionej piosenki, przy której dawno temu rozkwitało ich uczucie. Tajemniczy uśmiech rodzący się na twarzy Kate może oznaczać zarówno szczerą akceptację rzeczywistości, jak i ostateczną kapitulację wobec konwenansu. Niejednoznaczność tej reakcji objawia w miniaturze 
Zatem 45 lat to obraz poświęcony rozterkom związanym z uczuciami miłosnymi, uwrażliwiający na tę sferę ludzkiej - a może w szczególności kobiecej - wrażliwości, która, bez względu na upływ czasu, pozostaje naznaczona dojmującą potrzebą bliskości, lękiem o trwałość więzów uczuciowych i obawą przed odrzuceniem. Reżyser, czyniąc swoimi bohaterami parę ludzi mniej więcej siedemdziesięcioletnich i stawiając ich wobec konieczności dokonania bilansu życiowego, nadał tej tematyce dodatkowy ciężar egzystencjalny, windując przy tym do maksimum „stawkę”, której dotyczą dylematy bohaterów.

Geoff ostatecznie podczas jubileuszowej uroczystości wchodzi w rolę kochającego męża (w zasadzie nigdy z tej roli nie wypadł ${ }^{11}$ ): ze łzami wzruszenia wygłasza okolicznościową przemowę, w której zapewnia zgromadzonych o tym, że poślubienie Kate było najlepszą decyzją w jego życiu, i o swojej nieprzerwanej miłości do żony. Kate uśmiecha się stosownie, w podziękowaniu czule przytula męża, jednak gdy znika z centrum uwagi, jej twarz pochmurnieje. Kulminacja skrywanych, trudnych emocji następuje podczas wspólnego tańca. Osnuci niebieską poświatą małżonkowie wirują na zaciemnionym parkiecie w rytm piosenki Smoke Gets in Your Eyes zespołu The Platters ${ }^{12}$, której tekst mówi o miłosnym ogniu i zwątpieniu, narodzinach i zmierzchu gorącego uczucia:

całą maestrię reżyserską Haigha i sprawia, że 45 lat może zostać w naszej pamięci jeszcze długo po seansie"; P. Czerkawski, Święto niepewności [recenzja filmu 45 lat]; http://www.filmweb.pl/review/\%C5\%9Awi\%C4\%99to+niepewno\%C5\%9Bci-17854 [dostęp: 2.08.2019].

11 Wieczorem w przeddzień jubileuszu podenerwowana Katia wyrzuca mężowi, że ma wrażenie, jakby tamta kobieta odciskała piętno na wszystkim w ich życiu (na ich decyzjach, wyprawach, lekturach, słuchanej muzyce, wyborze psa, a zwłaszcza „na sprawach zasadniczych”): „Chciałabym powiedzieć ci wszystko. Myślę, że wiem wszystko. Ale nie mogę. Rozumiesz to?”. Geoff odpowiada, że rozumie, ale zapewnia, iż Katya „nigdy nie miała z tym nic wspólnego”. Małżonkowie zawierają swego rodzaju umowę - rano mają zacząć wszystko od nowa.

${ }_{12} \mathrm{Na}$ początku filmu małżonkowie wspólnie ustalają, że piosenka ta - grana niegdyś na ich weselu - najlepiej nadaje się na pierwszy taniec podczas jubileuszowej uroczystości. 
They ask me how I knew

My true love was true

I of course reply

'Something here inside

Cannot be denied'

They said

'Someday you'll find

All who love are blind

When your heart's on fire

You must realise

Smoke gets in your eyes'

So I chaffed them

And I gaily laughed

To think they could doubt my love

Yet today

My love has flown away

I am without my love

Now laughing friends deride

Tears I cannot hide

Oh, I smile and say

'When a lovely flame dies

Smoke gets in your eyes'

Now laughing friends deride

Tears I cannot hide

Oh, I smile and say

'When a lovely flame dies

Smoke gets in your eyes ${ }^{\prime 13}$.

Wybrzmiewa ostatnia zwrotka („Teraz przyjaciele kpią ze mnie / a ja nie mogę ukryć łez / więc uśmiecham się i mówię: / »Kiedy płomień miłości gaśnie / to dym spowija ci oczy«"). Po skończonym tańcu Geoff pozostawia Kate na parkiecie. Kamera przez chwilę pozwala nam kontemplować to, czego nie mogą dostrzec pozostali bohaterowie filmu: grymas zduszonego bólu na twarzy niemłodej już, lecz jeszcze pięknej kobiety.

${ }_{13}$ Piosenka powstała w 1933 r., autorem jej tekstu jest Otto Harbach. 


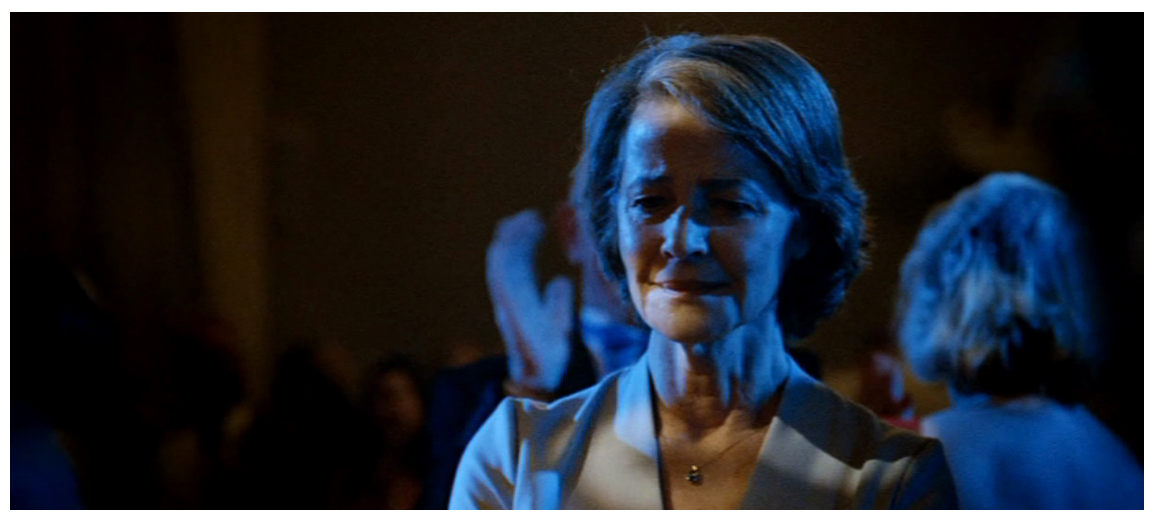

Il. 2. Kadr reprezentujący końcowe ujęcie filmu 45 lat (reż. Andrew Haigh). Mą̇ pozostawia Kate sama na parkiecie po tańcu inaugurującym jubileuszowa zabawę. Błękitna poświatę, która spowija salę, można interpretować metaforycznie - jako znak niemocy ${ }^{14} i$ dotkliwego smutku, jakie towarzysza poczuciu utraconej miłości (por. słowa piosenki Smoke Gets in Your Eyes)

\section{IV.}

Andrew Haigh nakręcił film subtelny i kameralny, w wyważony sposób mówiący o trudnej do uchwycenia złożoności uczuć miłosnych, które zdają się nieustannie oscylować między pragnieniem intymnej bliskości i wyłączności a lękiem zawodu, dojmującą tęsknotą za emocjonalną pełnią a poczuciem niespełnienia. Niekonwencjonalne i przez to szczególnie cenne w tym obrazie wydaje się wpisanie problemu dialektycznej złożoności życia wewnętrznego człowieka w kontekst starości i przemijania, co go dodatkowo egzystencjalnie wyostrza i komplikuje. Reżyser, ukazując swych siedemdziesięcioletnich bohaterów w momencie emocjonalnego kryzysu, który jest następstwem dramatycznej konfrontacji z odległą przeszłością, dowodzi, że zarówno ludzką uczuciowość, jak i tożsamość znamionują nieustanne wątpienie oraz proces przemian. „Nie wierzę, że ludzie przestają szukać odpowiedzi tylko dlatego, że się starzeją" - powie w wywiadzie Haigh. „Istnieje przekonanie, że przed trzydziestką powinniśmy mieć wszystko przepracowane i powinniśmy wiedzieć, kim jesteśmy. Jestem absolutnie

${ }^{14}$ P. Bellantoni, Jeśli to fiolet, ktoś umrze. Teoria koloru $w$ filmie, tłum. M. Dańczyszyn, Warszawa 2010, s. 84. 
pewien, że w większości przypadków tak to nie działa. Ciągle się zmieniamy, nasza tożsamość ciągle się rozwija, a więc zawsze zadajemy pytania. A przynajmniej powinniśmy"15.

V.

Marek Bieńczyk podkreśla, że „nieprzejrzystość egzystencji jest dzisiaj dogmatem filozofii i psychologii”'16. W przestrzeni sztuk fabularnych predysponowana do drążenia tematyki nieprzeniknioności i paradoksalności ludzkich uczuć wydaje się zwłaszcza literatura, która ze swej istoty dysponuje szczególnie wysublimowanymi możliwościami prowadzenia narracji. Ale również kino ma na tym polu godne odnotowania osiągnięcia, z których zresztą wiele opiera się na inspiracjach literackich - jak choćby niektóre obrazy Luisa Buňuela, słynna Łagodna (Une femme douce, 1968) Roberta Bressona, będąca adaptacją opowiadania Fiodora Dostojewskiego, czy bardziej nam współczesne Wygnanie (Izgnanie, 2007) Andrieja Zwiagincewa. Bohaterki dwóch ostatnich filmów to kobiety zdeterminowane przez pragnienie osiągnięcia absolutu miłości, co doprowadza je do samobójstwa, którego motywy pozostają nieczytelne dla otoczenia. Ich krwawy dramat, podobnie jak intymny dramat Kate, rozgrywa się w ciszy. Adam Garbicz, mówiąc o dziele Bressona, podkreśla, że „w tej historii chodzi o wewnętrzny kosmos ludzkiej psychiki, o uniwersalny problem trudności porozumienia się mężczyzny i kobiety [...]"17. Słowa te z powodzeniem można odnieść do wszystkich wymienionych powyżej filmów.

Istotnym tematem 45 lat, uwypuklonym już przez sam tytuł, jest przeszłość - przeszłość na co dzień niewidoczna, ale przecież nieprzerwanie „przyczajona” pod powierzchnią teraźniejszości. Jej ikoniczną (choć - jak wcześniej zaznaczyłam - jedynie wyobrażeniową) reprezentację stanowi motyw utraconej narzeczonej, która od półwiecza spoczywa w tafli lodu. Fakt, iż chodzi o ciało młodej kobiety, przedziwnym zbiegiem okoliczności zakonserwowane w substancji przezroczystej, na mocy implikacji

${ }^{15}$ Q \& A, op. cit.

16 M. Bieńczyk, op. cit., s. 63.

17 A. Garbicz, Kino, wehikuł magiczny. Przewodnik osiagnięć filmu fabularnego. Podróż czwarta 1967-1973, Kraków 2000, s. 100. 
intertekstualnych wnosi do tej w gruncie rzeczy prozaicznej opowieści pierwiastek niezwykłości i ma swoje konsekwencje w planie symbolicznym filmu.

Idea przezroczystości jest tak silnie zakorzeniona w wyobraźni, iż można dopatrywać się w niej charakteru archetypowego ${ }^{18}$. Do związanych z nią konceptów, które na trwałe wpisały się w zbiorową wyobraźnię, zalicza się np. (na obszarze dyskursów dotyczących władzy i państwowości) panoptikon Jeremy'ego Benthama czy chociażby młodopolską utopię szklanych domów, a w rejonach bliższych refleksji egzystencjalnej - właśnie wyobrażenie szklanej trumny.

Za najsłynniejszą przezroczystą trumnę w dziejach kultury uznać trzeba tę, w której spoczęła królewna Śnieżka, zanim po spożyciu zatrutego jabłka została wybudzona ze śmiertelnego snu przez zachwyconego jej urodą królewicza. Krasnoludki, opłakujące okrutny czyn zawistnej królowej, uznały, że nie potrafią ciała pięknej dziewczyny po prostu „oddać czarnej ziemi”"19 , kazały więc zrobić właśnie szklaną trumnę, aby zmarłą wciąż można było oglądać. Nie jest to zresztą jedyny utwór w zbiorze klasycznych baśni braci Grimm, w którym pojawia się tego rodzaju przedmiot: pod numerem 163 znaleźć tu można fabułę zatytułowaną ni mniej, ni więcej, tylko Szklana trumna ${ }^{20}$.

Badacze z kręgu psychoanalizy wiążą omawiany motyw ze swoistym „letargiem uczuciowym”, który ma poprzedzać w życiu jednostki etap gotowości do nawiązania bliskiej więzi z partnerem innej płci ${ }^{21}$. Andrew Haigh

18 Zob. M. Bieńczyk, op. cit., s. 88 .

19 Śnieżka, w: Baśnie braci Grimm, t. 1, tłum. E. Bielicka, M. Tarnowski, posł. i koment. H. Kapełuś, Warszawa 1982, s. 256.

20 Szklana trumna, [w:] Baśnie braci Grimm, op. cit., t. 2, s. 192-199.

${ }^{21}$ „W typowych interpretacjach psychoanalitycznych baśń ta [Szklana trumnaprzyp. B.P.J.] symbolizowałaby przejście dziewczyny od okresu dojrzewania do dorosłej seksualności (utożsamianej z małżeństwem). Takie właśnie wyjaśnienie daje Bruno Bettelheim w odniesieniu do słynnej szklanej trumny królewny Śnieżki. Uwolniwszy się od rywalizacji z matką, dziewczynka cofa się pod względem psychologicznym, kiedy znajduje schronienie u krasnoludków, po czym etapami dojrzewa pod wpływem trzech kolejnych wypraw starej handlarki [czyli przebranej złej królowej - przyp. B.P.J.] do lasu. W końcu epizod ze szklaną trumną wieńczy jej rozwój i poprzedza odrodzenie, czyli przebudzenie, do miłości i życia małżeńskiego"; P. Péju, Dziewczynka w baśniowym lesie. O poetykę baśni: w odpowiedzi na interpretacje psychoanalityczne i formalistyczne, tłum. M. Pluta, Warszawa 
zachowuje w swym filmie erotyczne (w szerokim tego słowa znaczeniu) konotacje przezroczystej „trumny”, wpisując jednocześnie ten motyw w dodatkowe szeregi znaczeniowe ${ }^{22}$. Najważniejsze $z$ nich są w sposób symboliczny powiązane z problematyką czasowości egzystencji ludzkiej i dochodzą do głosu w następujących wymiarach:

1. w wymiarze cielesności ${ }^{23}$ (młodości, starzenia się, fizycznego przemijania) - co w danym kontekście pozwala dopatrywać się w motywie lodowej „trumny” symbolu wiecznej młodości i niewygasającej namiętności;

2. w wymiarze tożsamości i „pracy pamięci” (blaknięcia, powracania, przemiany i trwania wspomnień) - co w tym kontekście pozwala, na prawach relacji metonimicznej, dopatrywać się w motywie lodowej „trumny” symbolu trwałości tych aspektów tożsamości bohatera, które pozostają w związku z daną relacją miłosną;

3. w wymiarze duchowości i „pracy uczuć” (zanikania, odnowy, trwania i przemiany uczuć) - co z kolei w danym kontekście każe dopatrywać się w motywie lodowej „trumny” symbolu nieprzerwanego trwania utraconej miłości.

Wskazane obszary znaczeń aktualizują się w filmie 45 lat, będącym nader subtelnym dramatem obyczajowym, w sposób niepełny, w zasadzie potencjalny i „dialogowy”. Zniuansowanie semantyczne oraz nacechowanie

2008, s. 50. Zob. B. Bettelheim, Królewna Śnieżka, [w:] idem, Cudowne i pożyteczne. O znaczeniach i wartościach baśni, tłum. i oprac. D. Danek, Warszawa 1996, s. 312-335.

22 Pamiętajmy, że - jak dowodził Italo Calvino - „każdy obraz generuje inne obrazy, tworząc pole analogii, symetrii, przeciwstawień”; I. Calvino, Przejrzystość, [w:] idem, Wykłady amerykańskie, tłum. A. Wasilewska, Warszawa 1996, s. 80.

${ }^{23}$ Za jeden $\mathrm{z}$ wymiarów cielesności w kinie uważa się „ekranowe fantazmaty, które percypujemy prawie tak samo jak rzeczywistość" (tak zwaną cielesność pozorną). Obok niej Tadeusz Miczka wyróżnia „cielesność” podmiotu wypowiedzi filmowej, który przekształca własne cielesne i percepcyjne doznania w formę symboliczną i projektuje je na świat przedstawiony filmu, oraz cielesność widza, uaktywniającą się podczas odbioru dzieła; T. Miczka, Cielesny aspekt podmiotowości w kinie, [w:] Kino: ciało - gest - ruch. Film w perspektywie systemów komunikowania niewerbalnego, red. A. Gwoźdź, Wrocław 1990, s. 128. 
afektywne omawianego motywu uzależnione są oczywiście od tego, z czyjej perspektywy - Kate czy Geoffa - spojrzymy na przedstawioną sytuację. Nie zmienia to jednak faktu, że reżyser filmu poprzez posłużenie się wyobrażeniem kobiety uwięzionej w przezroczystej tafli lodu i takie, a nie inne jego skontekstualizowanie odwołał się do wrażliwości fantazmatycznej widzów, dzięki czemu zdołał w sugestywny sposób ukazać rozterki wewnętrzne, ideały, lęki i dylematy uczuciowe swoich bohaterów. Wydaje się, że udało mu się odsłonić w owej „historii emocjonalnej” dwojga starszych ludzi rąbek tych doświadczeń wewnętrznych, które w swej intymnej subtelności pozostają z zasady nieprzejrzyste i niewyrażalne.

\section{Bibliografia}

Gaston Bachelard, Wyobraźnia poetycka. Wybór pism, wyb. H. Chudak, przedm.

J. Błoński, tłum. H. Chudak, A. Tatarkiewicz, PIW, Warszawa 1975.

Baśnie braci Grimm, t. 1 i 2, tłum. E. Bielicka, M. Tarnowski, posł. i koment.

H. Kapełuś, Ludowa Spółdzielnia Wydawnicza, Warszawa 1982.

Patti Bellantoni, Jeśli to fiolet, ktoś umrze. Teoria koloru w filmie, tłum.

M. Dańczyszyn, Wydawnictwo Wojciech Marzec, Warszawa 2010.

Bruno Bettelheim, Królewna Śnieżka, [w:] idem, Cudowne i pożyteczne. O znacze-

niach $i$ wartościach baśni, tłum. i oprac. D. Danek, W.A.B., Warszawa 1996.

Marek Bieńczyk, Przezroczystość, SIW Znak, Kraków 2007.

Italo Calvino, Przejrzystość, [w:] idem, Wykłady amerykańskie, tłum. A. Wasilewska, Marabut - Volumen, Gdańsk - Warszawa 1996.

Piotr Czerkawski, Święto niepewności [recenzja filmu 45 lat], Filmweb; http://www. filmweb.pl/review/\%C5\%9Awi\%C4\%99to+niepewno\%C5\%9Bci-17854.

Douwe Draaisma, Fabryka nostalgii. O fenomenie pamięci wieku dojrzałego, tłum.

E. Jusewicz-Kalter, Wydawnictwo Czarne, Wołowiec 2010.

Adam Garbicz, Kino, wehikuł magiczny. Przewodnik osiagnięć filmu fabularnego. Podróż czwarta 1967-1973, Wydawnictwo Literackie, Kraków 2000.

Tadeusz Miczka, Cielesny aspekt podmiotowości w kinie, [w:] Kino: ciało - gest ruch. Film w perspektywie systemów komunikowania niewerbalnego, red. A. Gwoźdź, Wiedza o Kulturze, Wrocław 1990.

Luiza Nader, Modi memorandi. Leksykon kultury pamięci, red. M. Saryusz-Wolska, R. Traba, Wydawnictwo Naukowe Scholar, Warszawa 2014.

Pierre Péju, Dziewczynka w baśniowym lesie. O poetykę baśni: wodpowiedzi na interpretacje psychoanalityczne i formalistyczne, tłum. M. Pluta, Sic!, Warszawa 2008. 
Q \& A, Wywiad z Andrew Haighem, materiały dołączone do wydania filmu 45 lat na płycie DVD, Solopan Sp. z o.o., 2015.

Grzegorz Sanik, Człowiek z Tollund - twarz sprzed ponad 2300 lat, 1.11.2015, Eloblog; https://eloblog.pl/czlowiek-z-tollund-twarz-sprzed-ponad-2300-lat/.

\section{The Fiancée on a Sheet of Ice - How the Cinema Talks about Impenetrable Feelings of Love}

The subject of analysis in the article is the 2015 British film 45 Years (dir. Andrew Haigh), which is an adaptation of David Constantine's novel In Another Country. The film presents an intimate image that, in a subtle way, talks about the complexity of feelings of love, constantly oscillate between the desire for intimate closeness and exclusiveness, and the fear of disappointment (longing for emotional fullness and a sense of failure). Inscribing the problem of the dialectical complexity of the emotional life of a man in the context of old age and transience seems unconventional and, therefore, particularly valuable in this film. An important theme in 45 Years, emphasised by the title itself, is the past; invisible on a daily basis, it lurks under the surface of the present. Its iconic (though only imaginary) representation is connected with the plot of the first, lost fiancée of the hero, whose remains - after half a century - are unexpectedly found on a Swiss glacier. The author of the article argues that the fact that it concerns a young woman's body (preserved in a transparent substance in a strange coincidence), by virtue of intertextual implications, brings an archetypal element to the essentially prosaic story; this archetypal element has then far-reaching consequences in the symbolic plan of the film. Skilful reference to the fairy-tale motif of the 'glass coffin' allowed the British director for portraying in this audio-visual story, which talks about the emotional dramas of two elderly people, an image of these internal experiences that in their intimate subtlety remain impenetrable and inexpressible.

Keywords: 45 Years, British cinema, love dilemmas in film, internal experience in film, theme of the glass coffin, the idea of opacity, the opacity/ impenetrable of existence, Andrew Haigh 